\section{Terrorism, Technology, and the Profession}

Neville Holmes, University of Tasmania

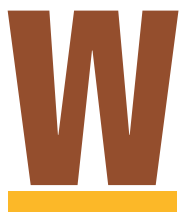

hen the wireless news woke me with a description of the terrorist mayhem in Manhattan and Washington on September 11 , a part of my mind refused to accept it. That part said this must be a spoof in much worse taste than the one Orson Welles broadcast in 1938, when he passed off a radio play of H.G. Wells's The War of the Worlds as a real alien invasion.

A few minutes later, when my television showed the unforgettable scene of a large commercial airliner flying into the south World Trade Center tower, that same part of my mind insisted that I must be watching a clip from a Hollywood technothriller. Its repetition and the commentary soon made the truth undeniable. Disbelief became grief, grief became tears, and going on with ordinary life became a struggle-even though the events thus affecting me were taking place on the other side of the world.

Later that morning, as I forced myself along to the lecture room where my students waited, my mind turned to what I should tell them-these young people hoping to join the computing profession-about their responsibility as professionals to a community that had just had technology so publicly used against it. I urged them to look at the tragedy and its circumstances from a professional and personal standpoint, to try as apprentice system analysts to understand what had happened and might yet happen, and to work as professionals toward a world system that would make such tragedies less likely.

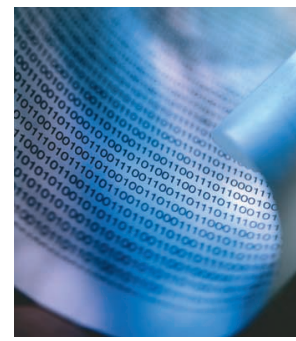

\title{
TECHNOLOGY AND TRAGEDY
}

Technology made the scale of this terrorist tragedy possible: It built both the towers and the planes that destroyed them, and it produced the funds and provided the communications the terrorists used to implement their plan. Much of this technology is digital.

\section{Although digital technology made the September 11th tragedy possible, it can also prevent such incidents while we work to eliminate terrorism's causes.}

The authorities had technology in place to predict and prevent terrorist acts such as this and, because of September 11's events, they will receive calls for much greater use of preventive technologies and systems. Much of this technology will be digital, and members of the computing profession will be heavily involved in its development.

Many computing professionals have great experience in preventive systems, particularly for the Internet, and this experience will surely be relevant to the antiterrorism effort. Their professional judgment should be used to evaluate proposals that, if accepted, will likely have a considerable effect on the conduct of everyday life, our freedom of movement and speech, and our personal privacy and liberties. bag end of the terrorist spectrum could well be the less dangerous end. So which ones do we wipe out, how do we find them, and how do we stop people from becoming terrorists in reaction to the removal of those who already are?

We must take a broader viewpoint, a system viewpoint. We must determine the components of organized terror and analyze what motivates and sustains terrorists. This project presents a huge challenge, but several important aspects of systematic terrorism can already be seen.

First, the system of international terrorism extends far beyond the network alleged to be responsible for the September 11th tragedy. It extends beyond the US and the Taliban. Moreover, the scale of the Manhattan massacre pales alongside the millions killed by terrorists

Continued on page 134 
The Profession

Continued from page 136

in Cambodia and, more recently, the many hundreds of thousands killed in Rwanda and Bosnia-Herzegovina (http:// www.worldhistory.com/worldhistory/ genocide/).

Second, although terrorists often use religion to justify their actions, religious belief does not provide the basis for terrorism. Richard Dawkins, of meme fame, wrote most eloquently against religion's role in terrorism ("Religion's Misguided Missiles,” 15 Sept. 2001, http://www. guardian.co.uk). "To fill a world with religion, or religions of the Abrahamic kind, is like littering the streets with loaded guns. Do not be surprised if they are used." But his shafts flew wide of the target: Atrocities in the name of religion are incited for sociopolitical reasons, not religious ones. Religion, like technology, is inherently neutral. Either can be used for good or evil. If the outcome is evil, it is the user's responsibility, not religion's or technology's.

Third, the terrorist atrocities of September 11 were not acts of mindless anger and hate. The terrorists planned and carried them out deliberately and systematically. Terrorist system projects are purposeful. To understand them, we must understand their purpose. Their perpetrators meant these particular acts to be highly symbolic, a declaration to the world. The people killed in these incidents were not targets, but rather "collateral casualties." That the terrorists targeted the Pentagon and, reportedly, the White House, implies that they meant to attack the US government. That they allocated two planes to the World Trade Center, however, strongly implies that it was their most significant target. They see

\section{The terrorist atrocities of September 11 were not acts of mindless anger and hate. They were carried out deliberately and systematically.}

world trade as their enemy, then, and they targeted the US government because of its perceived role in world trade.

\section{TERROR'S CONTEXT}

To effectively counter a terrorist system, we must first understand its context. The sociopolitical system of organized terror forms a subset of all sociopolitical systems. Given that the September 11th attacks targeted world trade, the world's sociopolitical system thus serves as the context for these terrorist incidents.

Undoubtedly, the issues at this level will be discussed and reviewed extensively in other publications. Such discussion will likely be fruitless because a variety of experts will steer it in different

\section{COMPUTER}

Circulation: Computer (ISSN 0018-9162) is published monthly by the IEEE Computer Society. IEEE Headquarters, Three Park Avenue, 17th Floor, New York, NY 10016 5997; IEEE Computer Society Publications Office, 10662 Los Vaqueros Circle, PO Box 3014, Los Alamitos, CA 90720-1314; voice +1 714821 8380; fax +1 714821 4010; IEEE Computer Society Headquarters, 1730 Massachusetts Ave. NW, Washington, DC 20036-1903. IEEE Computer Society membership includes \$14 for subscription of Computer magazine ( $\$ 14$ for students). Nonmember subscription rate available upon request. Single-copy prices: members $\$ 17.00$; nonmembers $\$ 20.00$. This magazine is also available in microfiche form.

Postmaster: Send undelivered copies and address changes to Computer, IEEE Service Center, 445 Hoes Lane, Piscataway, NJ 08855. Periodicals Postage Paid at New York, New York, and at additional mailing offices. Canadian GST \#125634188. Canada Post Publications Mail (Canadian Distribution) Agreement Number 0487910. Printed in USA.

Editorial: Unless otherwise stated, bylined articles, as well as product and service descriptions, reflect the author's or firm's opinion. Inclusion in Computer does not necessarily constitute endorsement by the IEEE or the Computer Society. All submissions are subject to editing for style, clarity, and space.

directions: political and social scientists, security experts, historians, economists, theologians, militarists, biochemists, financiers, and many more will each approach the issue from their own specialist perspective.

In this event, confusion will likely spring from each specialist perceiving the problem differently. The system professional's role will thus be to evaluate and reconcile these different perceptions and arrive at a problem definition as consistent as possible with all expert viewpoints.

The system analysts and engineers within our profession have an opportunity to make a generalist and convincing contribution to these debates. We face a tremendous problem. Solving problems is the forte of system analysts and engineers, whose traditional problem-solving method starts by determining the problem before designing its solution.

Once the problem is well defined, the system professional can search for and design solutions to it. Digital technology will then play an important role in most, if not all, possible solutions.

\section{THE POTENTIAL PROBLEM...}

It is too early to suggest that any particular analysis of the problem is correct, but some general conclusions seem obvious. If world trade was indeed the terrorists' symbolic target, it follows that they see their support as coming from those who feel victimized by world trade as it is now conducted. The most obvious sufferers of the world trade status quo are the inhabitants of the world's poorest countries.

For more than a decade, the United Nations Development Program has been drawing attention to the growing inequity in the world. Chapter One of the UNDP's 2001 report (http://www.undp.org/ hdr2001/chapterone.pdf) records that one survey found "The richest 10 percent of the US population $[0.5$ percent of the world's people] (around 25 million people) had a combined income greater than that of the poorest 43 percent of the world's people (around 2 billion people)." Those who point to overall economic growth to justify extended commercialization fail to recognize that, despite such 
growth, the gap between rich and pooras the UNDP reported-is widening.

Many of the world's poorest people live in Islamic North Africa and Southwest Asia. At the same time, these locations contain some of the world's largest oil fields and, thus, they are also home to some of the world's richest individuals. These people have become conspicuously rich thanks to the developed world'sand particularly the US's-need for fuel.

The poor see the resulting inequity clearly. Those who wish to make trouble find it easy under these circumstances to depict the US as the villain. The US's own actions in the area further these perceptions, as Deakin University's Scott Burchill noted ("What Matters Is Why," Australian Financial Review, 21 Sept. 2001, p. 8). Burchill describes how several significant incidents from the past 20 years have tarnished the US's reputation in the region. The list includes planes shot down, cities exposed to bombing and naval bombardments, ships sunk, soldiers and civilians killed by "peacekeeping" forces, ongoing military and financial support for Israel, the establishment of US military bases in the Gulf area, and support for corrupt and oppressive Arab regimes.

Burchill gives special emphasis to the 1998 attack on a factory in Khartoum, which was bombed into oblivion without warning and with great loss of life because of its suspected role as a bin Laden chemical weapons factory. Only after the bombing did it become clear that the factory actually produced pharmaceuticals, supplying the Sudan with 60 percent of its medicines.

Incidents such as these help explain why the world's numerous poor so bitterly resent the world's conspicuous rich. Such resentment and such inequity can only serve to sustain extremists and provide them with suicidal volunteers.

We must understand that it is the perception of severe inequity and oppression that generates extreme emotions. It would, I believe, be wrong to say that this perception is the only or even most direct cause of organized terror. But it is overwhelmingly obvious that this perception greatly assists organized terror. Likewise, it's highly probable that terrorism can- not be eliminated while this perception persists.

\section{...AND THE POSSIBLE SOLUTION}

Although severe inequity and extreme poverty may be the prime motivators of terrorist support, according to the UNDP's 2001 Report, a Robin Hood

\section{Although severe inequity and extreme poverty may be the prime motivators of terrorist support, merely redistributing the world's wealth will not eliminate them.}

approach to redistributing the world's wealth will not eliminate them. Instead, we must empower the poor, especially the poorest of the poor, to help themselvesand we must use technology to do so.

Third World poverty is a scandal, and much of the Third World is Islamic. Sadly, such poverty is much more visible to its victims than to those of us who hold the power to rescue them from it.

The UNDP supports educating and enhancing communications in the world's poorest regions, while The Economist advocates increased education in the developed countries. Both recommendations have merit. But in Britain, for example, spending on education has reached a 40-year low ("Labour Cut Education Spending to a Forty Year Low," The Guardian, 4 Sept. 2001, http://www. guardian. co.uk), yet the system remains hell-bent on "recruiting the best teachers from classrooms in developing countries." From the system analyst's viewpoint, this approach is global systematic lunacy.

We must make a greater investment in teacher training and the educational use of digital technology, for there can be no education without educators. The use of digital technology in education would be greatly aided if we set aside our marketing and profit priorities and instead manufactured stable, mass-produced machinery, then made it globally and cheaply available.
I doubt that we can look to the Internet to further education, however. As I have detailed elsewhere ("The Net, the Web, and the Children," Advances in Computers, vol. 55, Academic Press, San Diego, Calif., 2001), the commercialization of the Internet will likely render it about as useful for education as television and radio have turned out to be.

$T$ he computing profession is based on the study and design of complex systems. We therefore have not merely an opportunity, but a special responsibility, to take part in the discussions and debates that follow from the September 11th incidents. We all must use our particular training and experience to understand the problems involved and help others understand them.

The problem is international, and its solution must be international. The computing profession is international and should work with international organizations to help define and solve the problem. In particular, we should support the UNDP, which advocates using technology to reduce poverty and inequity in the world.

As things stand, we can plausibly condemn using technology-industrial, commercial, or military-to create poverty and inequity. To me it seems obvious that if the poor of the world could see technology as something they can use, and are being helped to use, to alleviate their abject misery and poverty, this more than anything else will remove the perceived need for terrorism.

Whatever the root causes of terrorism, we system professionals must make the facts plain and public. To spend one or two years now using technology to fight the wrong problem will only lengthen the recovery by 10,20 , or even 100 years. 萧

Neville Holmes is an honorary research associate and a lecturer under contract at the University of Tasmania's School of Computing. Contact him at neville.holmes @utas.edu.au. 